\author{
Behzad SABERI \\ Postgraduate of National Economy Dept. \\ Peoples' Friendship University of Russia \\ 6 Miklukho-Maklaya St., Moscow, Russia, 117198 \\ Phone: (925) 520-90-40 \\ e-mail: behzad.saberi@mail.ru
}

\title{
Problems of Iran's Automotive Industry Competitiveness
}

\begin{abstract}
Car industry is among the most important sectors of the Iranian economy, though recently it has experienced a rapidly mounting crisis. The present study aims to analyze latest trends in the sector and discover optimal ways to overcome crisis phenomena. One of the main problems is low competitiveness of its products, which is due to a set of economic and political factors. Rescinded sanctions against Iran have given a chance to change the situation, but under new conditions, it seems increasingly relevant to find out about mechanisms, which will maintain reasonable balance between attraction of foreign companies possessing leading-edge technologies with efficient protection of the national industrial interests. The research of Iran's existing state strategy and general situation in the sector enabled the author to suggest a number of mechanisms for reforming the industry. These mechanisms entail creation of joint ventures as well as the state's co-financing of modernization projects in the sector and national research and development.
\end{abstract}

JEL classification: L62, O30, E22

Keywords: competitiveness; automotive industry; research and development; R\&D; Iranian economy; product quality.

\section{Introduction}

$\mathrm{T}^{\mathrm{a}}$ king urgent crisis measures in the sphere of manufacturing has become a strong necessity for modern Iran's automotive industry. A set of economic, political and technologyrelated production problems has led to a fact that companies in the sector seriously fall behind their competitors. However, there are no obvious solutions for handling this crisis as yet. The present study is going to examine the key factors behind the competitiveness of the Iranian automotive industry's products and identify principal directions of the government policy on forming the national car market.

The world automotive industry perfectly exemplifies a global superindustry, the significance of which for national economies can hardly be overestimated. Car and related industries ensure substantial employment of working age people of any country, where cars are produced. The worldwide automotive industry is estimated to have a total cash flow of more than 2,790 billion US dollars with a total production capacity of approximately 90 million vehicles, employing (directly and indirectly) more than 48 million people [6].

In Iran, car industry plays a powerful role as well. Its total sales of 12 billion US dollars make up for approximately $19 \%$ of the total industry. Iran Khodro and Saipa, which are the largest Iranian automotive manufacturers, employ 54 and 48 thousand people respectively, and if taking into account the indirect employment, the number of people working for these companies exceeds 1.5 million, i.e. about $12 \%$ of working age population ${ }^{1}$. These indicators

${ }^{1}$ Discussing the national automobile. Available at: http://www.farsnews.com/newstext.php?nn= 13921006000659. (in Persian) 
make the automotive industry the country's second most significant industry after oil and gas. At the same time, the current state of affairs in the industry arouses apprehension. The first comes a relatively low level of profitability (around 4.5\%), what decreases its investment attractiveness and hampers further development. The second obstacle is insufficient scales of production. The share of the automotive industry in the country's GDP is just $2.5 \%$ compared to $10 \%$ in developed countries [4]. In the world production Iran ranks the $18^{\text {th }}$ with the market share of $1 \%$ (Fig. 1).

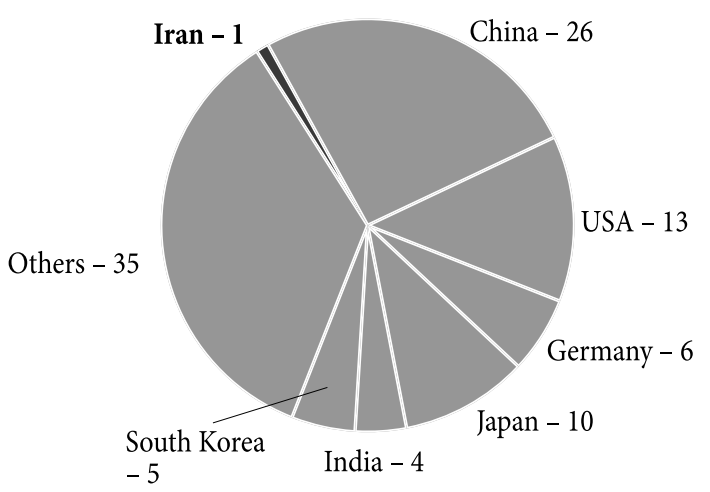

Fig. 1. Share of Iranian automotive manufacturers in the global car production in $2015, \%^{1}$

The third challenge is considerable underload of production facilities, which logically results in higher costs of production. The nominal production capacities of the Iranian enterprises are estimated to be more than 2 million cars a year, whereas actually in 2015 with great difficulties just 982337 vehicles were produced in the country ${ }^{2}$. The total vehicles production in Iran is ten times less than the production of one leader of the global auto industry such as Toyota or WV. Based on these data we can conclude that today the Iranian automotive industry does not fulfil the economic and social functions, which are assigned to it in the developed states.

\section{Trends and prospects of the Iranian automotive industry}

The Iranian automotive industry has a long history. The first Ford Model T arrived in Iran in the 1930s, and by 1955 the annual imports had risen to approximately 10, 000 units. In 1963, there was established the first automotive state-owned company Iran Khordo, which specialized in machine assembling while the parts were delivered from abroad. Iran Khordo and Saipa are the biggest car manufacturers in Iran, together they assume control over more than $79 \%$ of the domestic market ${ }^{3}$. Except for Iran Khordo and Saipa, there are some other smaller national brands: Pars Khodro, Kerman Khodro, Bahman Autos and Kish Khodro. They also produce various car models.

The production dynamics as well as sales of the Iranian vehicles in recent years are shown in Fig. 2. The data indicate that the industry's development is rather unstable: periods of growth give way to steep drops.

Throughout 2005-2011, the average growth rates of the Iranian car market amounted to $10 \%$ annually, yet the financial-economic crisis unleashed in 2012 changed the situation dramatically. First, the production fell by $38 \%$, and next year it declined by another $22 \%$. In 2014 ,

\footnotetext{
${ }^{1}$ Calculated using the OICA data. Available at: http://www.oica.net/

${ }^{2}$ OICA 2015 Production Statistics. Available at: http://www.oica.net/category/production-statistics/ 2015-statistics/.

${ }^{3}$ Iran's auto industry. Available at: http://theiranproject.com/blog/tag/irans-auto-industry/.
} 
the market recovered sharply after the crisis and grew by $37 \%$. The dynamics of car production correlates closely with the dynamics of car sales, though the latter reflects the impact of imported cars.

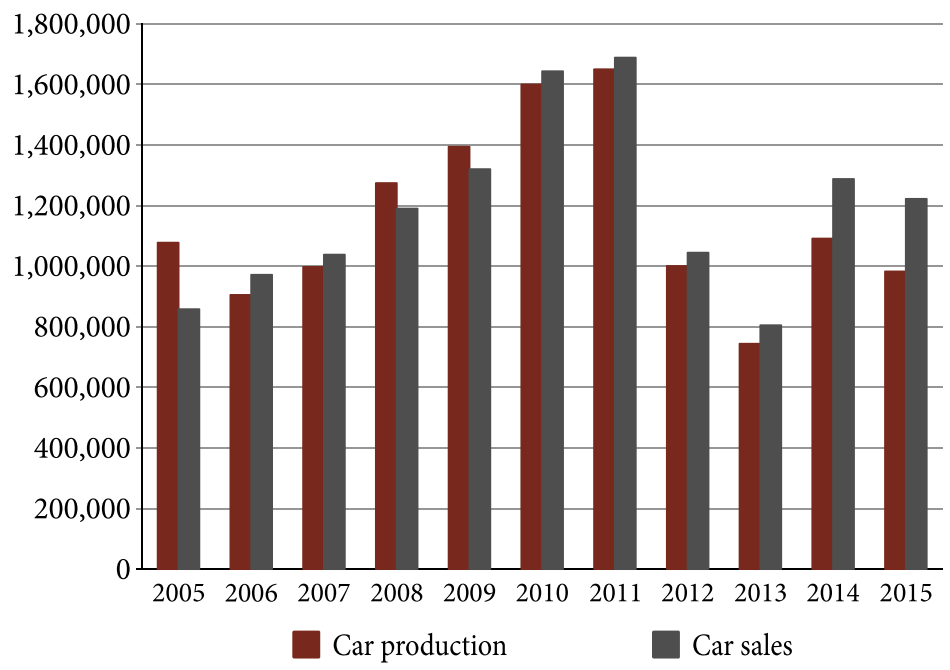

Fig. 2. Production dynamics and sales of all types of vehicles in Iran in 2000-2015, units per year ${ }^{1}$

The situation in the car market severely undermines the Iranian economy. After the years of economic decline car plants have found themselves on the brink of bankruptcy. To expand sales they resorted to various means from lending schemes to extended warranty period, etc. Nonetheless, the attempts to overcome the crisis in one particular sector taken outside the general economic policy context were not successful.

High dependence of the Iranian car market on the state of the country's economy did not allow employing local measures to support automotive industry. The connection between the volumes of car sales and cycles of the national economic development is confirmed by statistics. For instance, the upswing in the car market that started in 2014 (Fig. 2) was synchronous with the upswing in the general economic growth, whereas the recession in the Iran's economy that began at the end of 2011 and continued until 2014 corresponds to the slowdown in the national car market.

The statistics reveals that almost fifty years after the foundation of the Iranian automotive companies, they have not occupied a proper place in the global market. Obviously, this is due to the effect of economies of scale, where Iran loses to the European and especially to Chinese brands. Another factor behind the situation is the quality of the domestic products. Today car owners and potential buyers are distrustful of Iranian cars. A vivid example of such mistrust and offence of Iranian car owners was the creation of a group called "Kharide Khodroe Sefr Mamno" (Prohibition of the Purchase of New Cars) in social networks in 2015. It tried to persuade buyers not to purchase new cars of Iranian production. As a result, for a few months the population had actually reduced the purchases of new vehicles of national production, while the number of participants of this virtual community was growing.

These actions made the government take urgent measures. To stimulate demand, the buyers were given the right for a loan of 25 million rials (7,500 US dollars) for the purchase of the new locally produced cars. However, it was not enough, because it did not solve the main problem related to car quality [5]. In Iran, for years the buyers have been complaining about

${ }^{1}$ Calculated using the OICA data. Available at: http://www.oica.net/category/production-statistics/; http://www.oica.net/category/sales-statistics/ 
low quality of domestically produced cars and constantly criticizing the home automotive industry. Environmental problems of Iranian cars lead to air pollution in cities. Problems with car safety of Iranian cars have caused the death of more than 400,000 people on Iranian roads in the last twenty years. The soft loan did not solve these problems, and car sales in the Iranian market continued to decline.

A similar situation has arisen with the export of Iranian cars. Iran views the automotive industry as an important sector for exporting its products to neighboring countries, but the volume of this export has been decreasing year by year. This way, in 2012, the export of cars and car components amounted to 520 million US dollars, whereas in 2013 and 2014 it was just 263 and 243 million US dollars respectively ${ }^{1}$. The reason behind the fall in exports was the same insufficient competitiveness because of the poor quality and high prices [6].

The Iranian automobile industry bears an enormous burden of the accumulated problems. For many years, the national automotive market have been closed from the imports of the world's largest companies, and after political reforms, it appeared to be unprepared for open competition with the leaders of the global industry. The small volume of car imports into the country is indicative of the closedness of the automotive sector. For instance, the import of cars to the country during 2008-2014 was only 350,000 units, today Iran occupies the $75^{\text {th }}$ position in the world according to the volume of car imports. Keeping high duties on car imports combined with the existing monopoly of national brands has a marked negative effect ${ }^{2}$.

Experts argue that Iranian cars do not meet international standards, but even lacking quality in terms of ecology and safety they are offered at inflated prices with a considerable proportion of obsolete models. General inefficiency of management of the national economy, technological backwardness of the industry, absence of a modern auto component industry and continuing dependence on foreign component suppliers affect adversely the competitiveness of national brands. The country did not succeed in forming a competitive market for local suppliers of auto components, as a result, assembly plants are deprived of the opportunity to choose subcontractors and, thus, of exerting efficient economic influence on the cost and quality of their products. The industry plainly falls behind in terms of the level of investment in production and science.

The loss of a significant market share and customer dissatisfaction are linked not only with the low technical level of the national vehicles, but also with small investment into development of new platforms and models, limited number of models and options available to consumers. When an Iranian car manufacturer producers 1-3 fixed packages for every model, a foreign one offers 5-10 packages with a possibility of additional options and individual tailoring of an automobile to the needs of a buyer. Iranian companies invest several times less than their foreign competitors, what results from insufficient efficiency of financial mechanisms [2].

Like any other sector, automotive industry requires constant sources of financing, what became especially noticeable during the crisis [3]. At the moment, Iran's automotive industry is experiencing an acute shortage of investments. Over the last two decades, the Iranian car manufacturing plants have not modernized their main production assets substantially. Therefore, we can speak not only about a technology gap, but also about moral wear and tear of equipment. The service life of the key equipment in the industry exceeds 15 years. In the developed countries of the West the indicator usually varies from 10 to 11 years, and on average in the world car industry it equals 12.5 years. This also contributes to the reputation of Iranian cars as low-quality and obsolete, hampering their promotion in regional markets.

${ }^{1}$ Place of Iran in the global automotive industry. Available at: http://www.eghtesadonline.com/fa/ content/109882. (in Persian)

${ }^{2}$ Auto news $-26 \%$ of the Iranian cars are older than 20 years. Available at: http://hamshahrionline. ir/details/324570/Economy/Transport1. (in Persian) 
Since Iran lacks (partly or completely) such economic sectors as machine tool industry, electronics, etc., automotive companies have to purchase almost all equipment from foreign suppliers, and, hence, are technologically dependent on their competitors. Therefore, the problems of the car industry are systemic; the Iranian car manufacturers have practically no means to import modern equipment and technologies, and - what is worse - no locally developed ones. Improvement of the situation in certain areas cannot change the total picture, because the uneven development of the industry does not allow enhancing the quality of its products considerably.

The level of innovative activity of automotive companies predominantly rests upon renovation and modernization of the fixed assets. The development of a full-fledged automotive industry is impossible without having both a research and development base and intellectual property rights for the key elements, components, technical and technological solutions. At present, with rare exceptions ("Iran Khodro", "Saipa" and some others), automotive companies do not have advanced scientific and engineering centers. Design and technological departments existing at the enterprises are principally focused on handling current production problems. The implementation of special scientific and research projects by the state scientific organizations as well as projects partially financed from budgetary funds, definitely contributes to solving certain problems of scientific and technical development of the industry, but due to the fragmented engineering potential, it does not ensure the integration of goals and resources, coordination of actions on the design of automotive equipment of the new generation between the state and business.

It is worth mentioning the impact of economic sanctions against Iran on the country's automotive industry. The sanctions that were imposed in 2007 caused many difficulties for the national car industry, especially if taking into account the fact that was the time when national industry stood ready for massive expansion ${ }^{1}$. As it has already been noted, since 2012 the car production has gone down by approximately $50 \%$, whereas the car prices have gone up sharply by $300 \%$, leading to in the decline in the demand. Chinese companies took huge advantage of such situation and increased their presence in the Iranian car market through using the opportunities of cooperation with local car manufacturers. According to the HIS Automotive survey, in 2011 Chinese producers controlled just 1\% of the Iranian car market, whereas in 2015 their share grew up to $9 \%$. Some experts even began to talk about the threat of China's domination in the national car market of Iran [6].

\section{Ways and means of stimulating the industry's development}

After recent decisions on gradual lifting of the sanctions, the Iranian automotive industry has been given a new chance to become the main driving force of the Iranian economy. The last visits of delegations from Germany, Italy, France and Japan with the aim of developing cooperation, are a good reason for the shifts in the industry. Chances are that agreements on cooperation with international companies will be signed. Partnerships between Iran's automotive industry and large international companies may lead to an increase in direct investment and trigger technology transfer, as well as support car export, which, in turn, will raise the quality of the national brands. In addition, lifting of the sanctions will stimulate cooperation between car manufacturers and banks in terms of financial assistance to the former. The participation of the world leading automobile companies could help build new car production facilities and establish joint ventures for the manufacture of modern auto components. This will create a cheaper component base. However, it is worth remembering that foreign companies will pursue, first of all, their own interests, and the fate of national brands will remain under threat.

${ }^{1}$ Problems of the auto component sector. Available at: http://www.donyayekhodro.com/110759/. (in Persian) 
The current state of Iran's automotive industry may be described as critical. Unless comprehensive measures are taken at the state level to foster innovative development of the Iranian automotive industry, it can totally degrade in a few years or become completely dependent on foreign companies. That is why the Strategy for Iran's automotive industry development until 2025 suggests a "moderately innovative" scenario, conventionally called "The partnership". It involves the restructuring of the auto industry based on the active involvement of overseas partners and the organization of numerous joint ventures. According to this scenario, the state's efforts should be directed towards encouraging cooperation between Iranian and foreign companies and developing public-private partnerships in $\mathrm{R} \& \mathrm{D}$; funding part of the $\mathrm{R} \& \mathrm{D}$ expenditure of the national companies; providing state guarantees for loans to purchase licenses and carry out R \& D. At this, the share of foreign partners in joint ventures should not exceed 50\%. This restrictive measure will ensure a low share of direct imports, protecting the domestic car industry from stronger and more aggressive competitors.

The main areas of investment with the state participation, which are expected to contribute to the development of the national automotive industry include:

- Constructing new production facilities for the manufacture of cars, components and power units in order to meet the ever-increasing demand through domestic production.

- Modernizing and re-equipping existing production facilities to increase the competitiveness of products in terms of the efficiency, productivity and quality.

- Developing new national car platforms and models, components, and the equipment for production of these models, as well as researching the opportunities for the acquisition of licenses and adaptation of foreign car platforms within international cooperation.

- Providing working capital for automotive companies in the required volume to meet the forecasted growth in sales in the domestic market.

Association agreements between automobile corporations are another method for improving competitiveness and technological infrastructure of automakers [1]. International cooperation gives national companies a chance to overcome technological backwardness, yet the state should control these processes so as to avoid the acquisition of national companies. The principal problems of Iran's automotive industry are presented in the table.

The efficiency of the suggested measures is connected not only with economic situation in Iran itself, but with the political atmosphere in the region, because potential consumers of Iranian products include other countries of the Middle East. After rectifying the political problems, in the long view, we may talk about the relevance of production cooperation with neighboring countries. The problems of competitiveness of Iran's automotive industry are of systemic nature and cannot be settled in the short run; a long-term strategy is needed. The existing strategy has a plan, which implies that by 2025 the production volumes are to reach 3 million units a year, however, such forecasts raise serious doubt among experts. So far, the steps taken by the Iranian government to support national automotive industry have not generated any substantial positive effects, and experts argue that the implementation of the proposed strategy will actually result in the production not exceeding 2 million units. Selfevidently, at present any quantitative forecasts in the Iranian economy create distrust and are likely to be constantly revised. On the one hand, new trends have not manifested clearly yet, on the other hand, a lot depends on the political background and global energy prices, which are a critical factor behind Iran's revenues. Lastly, the efficiency of the general economic reforms and reforms of the public administration in the country are going to have an enormous impact. The automotive industry is strongly integrated into the national economy, that is why without any serious system changes in the state financial, innovation and education policies its effectual development is virtually impossible.

${ }^{1}$ Objectives and strategies of development of the automotive industry in Iran until 2025. Available at: http://www.asscc.ir/pdf/ahdaf1404.pdf. (in Persian) 
Key problems of Iran's automotive industry and ways of solving them

\begin{tabular}{|l|l|}
\hline \multicolumn{1}{|c|}{ Problems } & \multicolumn{1}{c|}{ Solutions } \\
\hline $\begin{array}{l}\text { Insufficient competitiveness: } \\
\text { Safety-, quality- and ecology-related problems of } \\
\text { Iranian cars; incompliance of these characteristics } \\
\text { with international standards. } \\
\text { Technological backwardness of the sector and } \\
\text { moral wear of equipment. } \\
\text { Customer dissatisfaction }\end{array}$ & $\begin{array}{l}\text { Encourage investment into development of new } \\
\text { platforms and models. } \\
\text { Strengthen research and development base. } \\
\text { Renovate and modernize the industry's fixed as- } \\
\text { sets }\end{array}$ \\
\hline $\begin{array}{l}\text { Lack of modern car component industry and } \\
\text { continuing dependence on foreign suppliers of } \\
\text { components }\end{array}$ & $\begin{array}{l}\text { Form a competitive market of the domestic sup- } \\
\text { pliers of auto components. } \\
\text { Impose local-content requirements for foreign car } \\
\text { manufacturers }\end{array}$ \\
\hline Shortage of investment & $\begin{array}{l}\text { Liberalize legislation in relation to foreign inves- } \\
\text { tors together with granting state guarantees and } \\
\text { retaining state control over their activities }\end{array}$ \\
\hline Insufficient scales of production & $\begin{array}{l}\text { Improve logistics. } \\
\text { Maintain cooperation between Iranian companies } \\
\text { producing materials and components. } \\
\text { Standardize auto components }\end{array}$ \\
\hline Irrational management & $\begin{array}{l}\text { Formulate clearly the state strategy for the sector } \\
\text { development. } \\
\text { Establish quantitative indicators and a system for } \\
\text { monitoring their achievement }\end{array}$ \\
\hline
\end{tabular}

The global experience shows that ideally modernization of equipment should take place at least every ten years. Such approach means making sizeable investments into the Iranian automotive industry. Outdated equipment does not allow manufacturing high-quality and competitive products. Despite largely bright prospects, the Iranian car industry encounters many serious problems: the volumes of production are not growing, profits are falling, huge investments into development of brand-new models and purchasing leading-edge technologies are needed, etc. For the sector's modernization, a solid base of Iranian suppliers of auto components is necessary. Another vital issue is that qualified national workforce is not in great demand in Iran's automotive industry, because their present qualification does not correspond to the requirements of modernization, thus, their retraining should be organized.

On the whole, a large-scale modernization of the engineering complex will only be possible with the focus on the general improvement of quality (products, management, research and development, etc.). The experience of foreign countries proves that automotive industry should occupy one of the most important places in the national economy. The car industry that complies with international standards and has globally competitive products enhances the efficiency of and stimulates the growth in other, related economic sectors.

\section{Conclusion}

Today the Iranian automotive industry is at a crossroads. On the one hand, the car industry ensures a significant share of employment. On the other hand, its products do not satisfy modern consumer preferences at all. Automotive industry in many respects needs to be built almost from scratch, and the key issue is to choose the right strategy. The first option available is to correct the situation counting only on the country's own resources; the second one is to attract leading foreign companies to assist in modernization and creation of new production facilities. It is also possible to choose the third option, and balance between the attraction of overseas companies and the support of national manufacturers. The last alternative seems to be the most acceptable, because it allows to retain control over the key economic sector. The 
success of such strategy has already been demonstrated by China and India. As for Iran, it is likely to defend its economic independence and rely on cooperation with German and French companies strictly within the framework of agreements on the establishment of joint ventures. Another thing to expect is an increase in the state participation in national research and development projects as well as projects of production modernization.

\title{
References
}

1. Aleksandrov I.A. Osnovnye tendentsii razvitiya mirovogo avtomobilestroeniya v sovremennykh usloviyakh [Key trends in the development of the global car manufacturer in modern conditions]. Novyy vzglyad. Mezhdunarodnyy nauchnyy vestnik - New Look. International Scientific Bulletin, 2013, no. 2, pp. 327-340.

2. Makarova V.I., Ostroukhova V.A., Kostin A.V. Osnovnye problemy i perspektivy razvitiya predpriyatiy avtomobil'noy promyshlennosti [Main problems and prospects of car manufacturing enterprises]. Vestnik Volzhskogo universiteta im. V. N. Tatishcheva - Vestnik of Volzhsky University after V.N. Tatishchev, 2014, no. 1(30).

3. Podkhalyuzina V.A., Ipatov A.A. O finansovykh potrebnostyakh Rossiyskoy avtomobil'noy promyshlennosti [On financial needs of the Russian automotive industry]. Vestnik Moskovskogo avtomobilno-dorozhnogo gosudarsvennogo tekhnicheskogo universiteta (MADI) - Bulletin of the Moscow Automobile an Road Construction State Technical University (MADI), 2015, no. 2(41), pp. 70-74.

4. Savilova Ye. V. Rossiyskoe avtomobilestroenie: problemy konkurentosposobnosti [Russian car industry: Problems of competitiveness]. Available at: http://www.unn.ru/pages/vestniki_ journals/99990193_West_econ_finans_2004_2(6)/92.pdf.

5. Gudarzi M. Problems of the Iranian automotive industry. Available at: http://www.otaghnews.com/news/317856/. (in Persian)

6. Hosseinifar H., Ebrahimzadeh A., Jünemann M. Iran Automotive Industry Outlook 2025. Available at: http://www.ilia-corporation.com/wp-content/uploads/2015/06/Automotive-Industry-Iran-ILIA-Corporation-White-Paper-c.pdf.

\section{Проблемы конкурентоспособности иранской автомобильной промышленности}

\author{
Бехзад Сабери
}

Автомобильная промышленность находится в числе важных секторов экономики Ирана, однако в последние годы в ней быстро нарастают кризисные явления. Целью настоящего исследования является анализ сложившихся тенденций в отрасли и поиск оптимальных путей выхода из кризиса. Одной из главных проблем остается низкая конкурентоспособность продукции, что вызвано совокупностью экономических и политических факторов. Отмена санкций против Ирана дает шанс изменить ситуацию, но в новых условиях представляется крайне актуальным найти механизмы, которые обеспечат разумное сочетание объемов привлечения иностранных компаний с их передовыми технологиями и эффективной защиты национальных промышленных интересов. Исследование государственной стратегии Ирана и ситуации в автомобильной промышленности позволило предложить ряд механизмов реформирования отрасли: создание совместных предприятий, государственное софинансирование проектов технического перевооружения отрасли и национальных НИОКР.

Ключевые слова: конкурентоспособность; автомобильная промышленность; НИОКР; Иранская экономика; качество продукции. 


\section{Источники}

1. Александров И.А. Основные тенденции развития мирового автомобилестроения в современных условиях: новый взгляд // Международный научный вестник. 2013. № 2. С. 327-340.

2. Макарова В.И., Остроухова В.А., Костин А.В. Основные проблемы и перспективы развития предприятий автомобильной промышленности // Вестник Волжского университета им. В. Н. Татищева. 2014. № 1 (30). С. 116-126.

3. Подхалюзина В.А., Ипатов А.А. О финансовых потребностях российской автомобильной промышленности // Вестник Московского автомобильно-дорожного государственного технического университета (МАДИ). 2015. № 2 (41). С. 70-74.

4. Савилова Е. В. Российское автомобилестроение: проблемы конкурентоспособности. URL: http://www.unn.ru/pages/vestniki_journals/99990193_West_econ_finans_2004_2(6)/92.pdf.

5. Gudarzi M. Problems of the Iranian automotive industry. URL: http://www.otaghnews.com/ news/317856/. (in Persian)

6. Hosseinifar H., Ebrahimzadeh A., Jünemann M. Iran Automotive Industry Outlook 2025. URL: http://www.ilia-corporation.com/wp-content/uploads/2015/06/Automotive-Industry-Iran-ILIA-Corporation-White-Paper-c.pdf.

Сведения об авторе:

Бехзад Сабери, аспирант кафедры

Российский университет дружбы народов национальной экономики 117198, РФ, г. Москва, ул. Миклухо-Маклая, 6

Контактный телефон: (925) 520-90-40

e-mail: behzad.saberi@mail.ru 